\title{
Analisis Penggunaan Model Pembelajaran Numbered Head Together pada Mata Pelajaran Otomatisasi Tata Kelola Kepegawaian di SMKN 1 Lamongan
}

\author{
Inez Windi Harum, Durinda Puspasari \\ Universitas Negeri Surabaya, Surabaya, Indonesia \\ Email authors: inez.17080314016@mhs.unesa.ac.id/durindapuspasari@unesa.ac.id
}

\begin{abstract}
ABSTRAK
Tujuan penelitian ini adalah untuk menganalisis penggunaan model pembelajaran Numbered Head Together (NHT) pada Mata Pelajaran Otomatisasi Tata Kelola Kepegawaian di SMKN 1 Lamongan. Adanya analisis tersebut adalah untuk mengetahui kesesuaian penggunaan model pembelajaran Numbered Head Together (NHT) terhadap sintaks model pembelajaran Numbered Head Together (NHT).Penelitian ini merupakan penelitian deskriptif dengan pendekatan kualitatif. Teknik pengumpulan data yang digunakan dalam penelitian yaitu wawancara terstandar dan angket kepada siswa kelas XII OTKP 1 di SMKN 1 Lamongan. Keabsahan data dalam penelitian ini menggunakan triangulasi sumber. Teknik analisis data menggunakan Model Miles dan Huberman yang terdiri dari pengumpulan data, reduksi data, penyajian data, dan penarikan kesimpulan. Hasil penelitian menunjukkan bahwa model pembelajaran Numbered Head Together (NHT) merupakan model pembelajaran yang menuntut siswa untuk dapat saling berdiskusi dengan kelompoknya sehingga proses pembelajaran menjadi lebih komunikatif. Adanya model pembelajaran NHT dapat melatih rasa tanggung jawab siswa terhadap tugas yang diberikan oleh guru serta dapat melatih keberanian siswa untuk mengungkapkan pendapatnya baik di dalam kelompok maupun di depan kelas.
\end{abstract}

Kata Kunci: Model Pembelajaran Numbered Head Together; Otomatisasi Tata Kelola Kepegawaian

\section{PENDAHULUAN}

Pendidikan merupakan salah satu aspek dalam kehidupan yang memegang peranan yang sangat penting. Tinggi rendahnya kualitas pendidikan pada suatu negara dipengaruhi oleh banyak faktor, antara lain dapat berasal dari mahasiswa, pengajar, sarana prasarana, dan bisa juga karena faktor lingkungan (Sembiring, 2014). Kualitas sumber daya manusia bergantung pada kualitas pendidikan. Kegiatan proses belajar mengajar di sekolah merupakan usaha dalam meningkatkan kualitas pendidikan, karena sekolah merupakan salah satu perangkat pendidikan yang bersifat formal (Hutahean, 2014). Kurikulum yang diterapkan di Indonesia adalah kurikulum 2013 yang mengalami revisi dimana yang awalnya kurikulum 2013 menjadi kurikulum 2013 revisi. Adanya perubahan kurikulum tersebut pembelajaran menjadi berpusat pada siswa, variatif dan interaktif, serta memberdayakan siswa secara maksimal. Penerapan kurikulum tersebut diharapkan dapat memaksimalkan dan meningkatkan profesionalisme guru dalam rangka mengelola proses pembelajaran, sehingga dapat menghasilkan pembelajaran yang menyenangkan, bermakna, berpikir kritis, kreatif, dan mandiri (Mislani, 2018). Dalam hal ini guru dituntut agar kegiatan pembelajaran lebih terpusat pada siswa dan menjadikan siswa untuk lebih komunikatif dan kreatif, hal ini juga tidak terlepas dari peran guru dalam memberikan pengetahuan serta keterampilan. Untuk itu sebelum memulai pembelajaran di kelas penting sekali bagi seorang guru untuk memilih dan menentukan model pembelajaran apa yang cocok untuk diterapkan sehingga siswa lebih termotivasi untuk belajar.

Salah satu model pembelajarn yang dapat menjadikan siswa lebih komunikatif adalah model pembelajaran kooperatif tipe Numbered Head Together (NHT). Model pembelajaran NHT adalah suatu model pembelajaran yang lebih mengedepankan pada aktivitas siswa dalam mencari, mengolah, dan melaporkan informasi dari berbagai sumber yang akhirnya 
dipresentasikan di depan kelas (Fathurrohman, 2017). NHT adalah model pembelajaran yang memberikan kesempatan kepada siswa untuk berdiskusi dan meningkatkan kerja sama. Terdapat beberapa penelitian terdahulu yang relevan dengan model pembelajaran NHT. Penelitian yang dilakukan oleh Lestari, dkk (2020) menunjukkan bahwa penggunaan model pembelajaran NHT di kelas X SMA Swasta Bina Artha telah dilaksanakan sesuai dengan langkah-langkah pembelajaran model NHT dengan kategori sangat baik. Hariana (2018) dalam penelitiannya menyebutkan bahwa adanya peningkatan hasil belajar siswa setelah diterapkan model pembelajaran kooperatif tipe NHT. Penelitian ini juga sejalan dengan penelitian yang dilakukan Fauzi, et al (2020) yang menunjukkan bahwa penerapan NHT untuk pembelajaran teks deskriptif kepada siswa kelas X telah berhasil.

SMKN 1 Lamongan merupakan Sekolah Menengah Kejuruan di kota Lamongan dengan akreditasi A dan memiliki program studi Otomatisasi Tata Kelola Perkantoran (OTKP), dimana terdapat dua kelas pada kelas XII yaitu OTKP 1 dan OTKP 2. Fokus penelitian adalah siswa kelas XII OTKP 1. Terdapat salah satu mata pelajaran produktif pada program studi OTKP yaitu mata pelajaran Otomatisasi Tata Kelola Kepegawaian yang memberikan segala informasi yang berkaitan dengan masalah kepegawaian yang ke depannya diharapkan dapat membantu para siswa untuk memasuki dunia kerja, dimana materinya terdiri dari macam-macam pensiun, cara pembiayaan pensiun, pendaftaran pensiun dan dokumen yang diperlukan untuk pengurusan pensiun. Guru menggunakan model pembelajaran NHT dengan tujuan agar dapat merangsang siswa untuk saling berdiskusi dan bekerja sama, serta menciptakan suasana pembelajaran yang komunikatif. Adapun tujuan dalam penelitian ini adalah untuk menganalisis penggunaan model pembelajaran NHT pada mata pelajaran Otomatisasi Tata Kelola Kepegawaian di SMK Negeri 1 Lamongan.

Menurut Fatimatuzzahroh \& Puspasari (2021), learning is a process of obtaining knowledge in which there is communication between students and teachers at a time, whether it is done face to face directly or remotely or indirectly using media or infrastructure. This interaction is an effort to change the attitudes of students from uneducated to more educated. Dengan kata lain pembelajaran merupakan suatu proses belajar dimana terdapat interaksi antara siswa dengan guru pada suatu waktu, baik dilakukan secara langsung dengan tatap muka maupun secara tidak langsung dengan menggunakan media atau sarana prasarana. Interaksi tersebut merupakan sebuah upaya untuk mengubah sikap siswa dari yang belum terdidik menjadi lebih terdidik. Model pembelajaran kepala bernomor (Numbered Head Together) dikembangkan oleh Spencer Kagan. Tipe model ini memberikan kesempatan kepada siswa untuk saling membagikan ide-ide dan mempertimbangkan jawaban yang paling tepat. Langkah-langkah model pembelajaran NHT telah dikembangkan oleh Fathurrohman (2017) menjadi 6 langkah sebagai berikut: Langkah 1 Persiapan: guru mempersiapkan rancangan pelajaran dengan membuat Skenario Pembelajaran (SP), Lembar Kerja Siswa (LKS) yang sesuai dengan model pembelajaran NHT; Langkah 2 Pembentukan Kelompok: guru membagi para siswa menjadi beberapa kelompok yang beranggotakan 3-5 orang siswa. Guru memberi nomor kepada setiap siswa dalam kelompok dan nama kelompok yang berbeda; Langkah 3 Pengamatan: tiap kelompok harus memiliki buku paket atau panduan dalam pembentukan kelompok, agar memudahkan siswa dalam menyelesaikan LKS atau masalah yang diberikan oleh guru; Langkah 4 Diskusi Masalah: dalam kerja kelompok setiap siswa berfikir bersama untuk menggambarkan dan meyakinkan bahwa tiap orang mengetahui jawaban dari pertanyaan yang telah ada dalam LKS atau pertanyaan yang telah diberikam oleh guru; Langkah 5 Memanggil Nomor Anggota atau Pemberian Jawaban: guru menyebut satu nomor dan para siswa dari tiap kelompok dengan nomor yang sama mengangkat tangan dan menyiapkan jawaban kepada siswa di kelas; Langkah 6 Memberikan Kesimpulan: guru 
bersama siswa menyimpulkan jawaban akhir dari semua pertanyaan yang berhubungan dengan materi yang disajikan.

\section{METODE PENELITIAN}

Penelitian ini merupakan penelitian deskriptif dengan pendekatan kualitatif. Penelitian deskriptif digunakan untuk menghasilkan kesimpulan yang luas untuk dipergunakan sebagai analisis. Penelitian kualitatif digunakan untuk meneliti pada kondisi obyek yang alamiah, dimana peneliti adalah sebagai instrumen kunci (Sugiyono, 2019). Teknik pengumpulan data yang digunakan dalam penelitian yaitu wawancara terstandar kepada 5 siswa sebagai subjek penelitian dengan berbantuan video call whatsapp yang terdiri dari 30 pertanyaan dan angket yang diberikan melalui google form kepada 36 siswa kelas XII OTKP 1 di SMKN 1 Lamongan yang terdiri dari 19 butir pernyataan sebagai data pendukung dengan menggunakan skala likert. Keabsahan data dalam penelitian ini menggunakan triangulasi sumber. Triangulasi sumber dalam penelitian ini adalah 2 siswa dan 1 guru mata pelajaran Otomatisasi Tata Kelola Kepegawaian. Teknik analisis data menggunakan Model Miles dan Huberman yang terdiri dari pengumpulan data, reduksi data, penyajian data, dan penarikan kesimpulan (Sugiyono, 2019).

\section{HASIL DAN PEMBAHASAN}

\section{Analisis Penggunaan Model Pembelajaran Numbered Head Together (NHT) pada Mata Pelajaran Otomatisasi Tata Kelola Kepegawaian di SMKN 1 Lamongan}

Berdasarkan hasil penelitian yang telah dilakukan oleh peneliti melalui wawancara dan angket kepada subjek penelitian dan triangulasi sumber, untuk menganalisis penggunaan model pembelajaran NHT pada mata pelajaran Otomatisasi Tata Kelola Kepegawaian di SMKN 1 Lamongan berdasarkan sintaks menurut Fathurrohman (2017) dijelaskan sebagai berikut:

\section{Langkah 1 Persiapan}

Hasil wawancara peneliti dengan subjek penelitian dan triangulasi sumber menyatakan bahwa pada langkah ini guru menyiapkan skenario pembelajaran beserta materi dan penugasan yang akan diberikan pada siswa. Pembuatan skenario pembelajaran disesuaikan dengan model pembelajaran NHT. Hal ini dapat dilihat dari perolehan angket bahwa langkah pertama dalam penggunaan model pembelajaran NHT adalah dengan melakukan persiapan yang diperoleh persentase sebesar 30,6\% siswa sangat setuju; 38,9\% siswa setuju; dan $27,8 \%$ siswa netral. Sehingga persentase terbanyak sebesar $38,9 \%$ siswa memilih setuju bahwa guru melakukan persiapan dengan membuat skenario pembelajaran terlebih dahulu sesuai dengan model pembelajaran NHT. Hal ini sesuai dengan hasil penelitian yang dilakukan oleh Turangan (2017) yang menyatakan bahwa pada tahap pertama guru mempersiapkan Skenario Pembelajaran (SP) terlebih dahulu. Tujuan dari pembuatan skenario pembelajaran untuk mengetahui tahapan-tahapan yang akan dilakukan, sehingga proses pembelajaran selama menggunakan model pembelajaran NHT dapat berjalan lancar. Setelah menyiapkan skenario pembelajaran guru juga mempersiapkan Lembar Kerja Siswa (LKS) yang terdapat penugasan dalam bentuk kelompok yang sesuai dengan model pembelajaran NHT. Hal ini dapat dilihat dari perolehan angket bahwa guru telah mempersiapkan terlebih dahulu rancangan pembelajaran berupa LKS yang sesuai dengan model pembelajaran NHT yang diperoleh persentase sebesar 22,2 \% siswa sangat setuju; $41,7 \%$ siswa setuju; dan 33,3\% siswa netral. Sehingga persentase terbanyak sebesar $41,7 \%$ siswa memilih setuju bahwa guru juga 
menyiapkan LKS yang sesuai dengan model pembelajaran NHT. Hal ini sesuai dengan hasil penelitian yang dilakukan oleh Widyastuti (2016) yang menjelaskan bahwa pada tahap ini guru mempersiapkan LKS dan membuat soal atau penugasan yang nantinya akan diberikan pada siswa selama proses pembelajaran menggunakan model pembelajaran NHT.

Sebelum memulai pembelajaran guru membuka pelajaran dengan mengucapkan salam dan berdoa bersama, kemudian guru memberikan motivasi kepada siswa agar selalu semangat dalam proses pembelajaran. Hal ini dapat dilihat dari perolehan angket bahwa guru mengucapkan salam dan memberikan motivasi kepada siswa sebelum kegiatan pembelajaran dimulai yang diperoleh persentase sebesar 66,7\% siswa sangat setuju; $25 \%$ siswa setuju; dan $8,3 \%$ siswa menjawab netral. Sehingga persentase terbanyak sebesar $66,7 \%$ siswa sangat setuju bahwa guru mengucapkan salam dan memberikan motivasi kepada siswa sebelum memulai kegiatan pembelajaran NHT. Hal ini sesuai dengan hasil penelitian yang dilakukan oleh Rahayu (2018) yang mengatakan bahwa setelah membuka pelajaran guru memberikan motivasi di awal pembelajaran. Motivasi ini diberikan sebelum proses belajar dimulai dan diharapkan dapat meningkatkan semangat siswa ketika mengikuti proses pembelajaran selama menggunakan model pembelajaran NHT. Selanjutnya guru memberikan penjelasan tentang prosedur model pembelajaran NHT yang terdapat pada Skenario Pembelajaran (SP) agar siswa memahami bagaimana prosedur model pembelajaran NHT yang akan digunakan dalam proses pembelajaran. Hal ini dapat dilihat dari perolehan angket bahwa guru memberikan penjelasan tentang prosedur model pembelajaran NHT pada awal pembelajaran yang diperoleh persentase sebesar 44,4\% siswa sangat setuju; 36,1\% siswa setuju; dan 19,4\% siswa netral. Sehingga persentase terbanyak sebesar $44,4 \%$ siswa sangat setuju bahwa guru memberikan penjelasan tentang prosedur model pembelajaran NHT sebelum memulai kegiatan pembelajaran. Hal ini sesuai dengan hasil penelitian yang dilakukan oleh Fauziah (2020) yang mengungkapkan bahwa setelah guru memberikan motivasi pada siswa guru menjelaskan prosedur atau langkah-langkah model pembelajaran NHT.

\section{Langkah 2 Pembentukan Kelompok}

Hasil wawancara peneliti dengan subjek penelitian dan triangulasi sumber menyatakan bahwa pada langkah ini yaitu pembentukan kelompok dimana terdapat 36 siswa yang dibagi menjadi 6 kelompok dan masing-masing kelompok beranggotakan 6 orang siswa. Setelah kelompok terbentuk maka masing-masing siswa berkumpul bersama dengan kelompoknya. Hal ini dapat dilihat dari perolehan angket bahwa guru membagi siswa menjadi beberapa kelompok yang diperoleh persentase sebesar 38,9\% siswa sangat setuju; $44,4 \%$ siswa setuju; dan $16,7 \%$ siswa netral. Sehingga persentase terbanyak sebesar $44,4 \%$ siswa setuju bahwa guru membagi siswa menjadi beberapa kelompok. Hal ini sesuai dengan hasil penelitian yang dilakukan oleh Simanungkalit (2020) dan Wibowo (2018) yang menjelaskan bahwa pada tahap pembagian kelompok ini siswa dibagi 6 kelompok kecil, pembagian kelompok tersebut dilakukan secara heterogen. Hal ini bertujuan agar semua siswa dapat bekerja sama tanpa membedakan jenis kelamin.

Selanjutnya guru memberi nomor kepada setiap siswa dalam kelompok dan nama kelompok dengan nama yang berbeda. Upaya ini dilakukan agar semua siswa merasa siap ketika sewaktu-waktu nomornya dipanggil oleh guru untuk mempresentasikan hasil diskusi kelompoknya. Hal ini dapat dilihat dari perolehan angket bahwa guru memberi nomor kepada siswa dalam kelompok dan nama kelompok yang berbeda yang diperoleh persentase sebesar $33,3 \%$ siswa sangat setuju; 38,9\% siswa setuju; dan $25 \%$ siswa netral. Sehingga persentase terbanyak sebesar 38,9\% siswa setuju bahwa guru memberi nomor kepada setiap siswa dalam kelompok dan nama kelompok yang berbeda. Hal ini sesuai dengan hasil penelitian yang dilakukan oleh Nurhadisah, Halim, \& Khaldun (2014) yang mengatakan bahwa tahap 
pemberian nomor ini dilakukan setelah guru membentuk kelompok, setiap siswa dalam anggota kelompok memiliki nomor yang berbeda sehingga semua siswa memiliki peluang untuk mempresentasikan hasil diskusinya di depan kelas.

\section{Langkah 3 Pengamatan}

Hasil wawancara peneliti dengan subjek penelitian dan triangulasi sumber menyatakan bahwa pada langkah ini siswa diharuskan untuk mempunyai buku paket untuk mempermudah siswa dalam menyelesaikan tugas pada LKS yang diberikan oleh guru. Hal ini dapat dilihat dari perolehan angket bahwa guru menyampaikan kepada setiap kelompok agar memiliki buku paket untuk mempermudah siswa dalam menyelesaikan soal yang terdapat dalam LKS yang diperoleh persentase sebesar 38,9\% siswa sangat setuju; 41,7\% siswa setuju; dan 16,7\% siswa netral. Sehingga persentase terbanyak sebesar $41,7 \%$ siswa setuju bahwa guru menyampaikan agar setiap kelompok harus memiliki buku paket untuk mempermudah siswa dalam menyelesaikan LKS. Hal ini sesuai dengan hasil penelitian yang dilakukan oleh Sujatna (2014) yang mengemukakan bahwa siswa harus mempunyai LKS dan guru juga mempersiapkan Silabus, Rencana Pelaksanaan Pembelajaran (RPP) dan LKS beserta dengan penugasan yang akan diberikan. Selanjutnya, guru melakukan pengamatan kepada setiap kelompok dalam menyelesaikan penugasan yang ada di LKS. Pengamatan ini bertujuan untuk mengetahui seberapa jauh tingkat pemahaman siswa terhadap materi pembelajaran dengan menggunakan model pembelajaran NHT. Hal ini dapat dilihat dari perolehan angket bahwa guru melakukan pengamatan kepada setiap kelompok dalam menyelesaikan soal yang terdapat dalam LKS yang diperoleh persentase sebesar 33,3\% siswa sangat setuju; 38,9\% siswa setuju; dan $27,8 \%$ siswa netral. Sehingga persentase terbanyak sebesar $38,9 \%$ siswa setuju bahwa guru melakukan pengamatan kepada setiap kelompok dalam menyelesaikan LKS. Hal ini sesuai dengan hasil penelitian yang dilakukan oleh Siregar (2016) dan Zaura, Elianti, \& Syah (2018) yang mengungkapkan bahwa selama proses pembelajaran guru melakukan pengamatan, hal ini bertujuan agar guru mengetahui partisipasi siswa dalam kelompok tersebut.

\section{Langkah 4 Diskusi Masalah}

Hasil wawancara peneliti dengan subjek penelitian dan triangulasi sumber menyatakan bahwa pada langkah ini guru meminta siswa untuk dapat bekerja sama dengan kelompoknya dan saling mengungkapkan pendapatnya, siswa juga dapat bertukar pikiran sehingga menemukan solusi bersama. Setelah menemukan solusi hal yang dilakukan oleh siswa adalah membuat kesepakatan bersama dengan membagi tugas atau permasalahan sehingga semua anggota kelompok ikut serta dalam mengerjakan tugas kelompok tersebut. Kemudian semua anggota kelompok masing-masing mengungkapkan pendapatnya dan apabila terdapat kekurangan maka anggota kelompok lain dapat memberi masukan ataupun tambahan. Hal ini dapat dilihat dari perolehan angket bahwa guru meminta dalam kerja kelompok setiap siswa berfikir bersama untuk menggambarkan dan meyakinkan setiap orang mengetahui jawaban dari pertanyaan yang telah ada dalam LKS yang diperoleh persentase sebesar 33,3\% siswa sangat setuju; $50 \%$ siswa setuju; dan 16,7\% siswa netral. Sehingga persentase terbanyak sebesar 50\% siswa setuju bahwa guru meminta dalam kerja kelompok, setiap siswa harus berfikir bersama agar dapat meyakinkan tiap orang mengetahui jawaban dari pertanyaan yang terdapat di LKS atau dari guru. Hal ini sesuai dengan hasil penelitian yang dilakukan oleh Khairina, Zamakhsyari, \& Hidayat (2017) dan Sulfiani (2016) yang mengemukakan bahwa setelah tugas diberikan oleh guru selanjutnya guru meminta siswa untuk mendiskusikan jawaban yang benar bersama dengan kelompoknya, dalam hal ini guru juga memastikan bahwa tiap anggota kelompok dapat mengerjakan dan mengetahui jawabannya sehingga 
ketika nanti nomor dari salah satu anggota kelompok dipanggil oleh guru semuanya sudah siap. Hal ini dapat dilihat dari perolehan angket bahwa guru memberikan pertanyaan bervariasi yang bersifat spesifik sampai yang bersifat umum untuk diskusi masalah yang diperoleh persentase sebesar $27,8 \%$ siswa sangat setuju; $41,7 \%$ siswa setuju; dan $27,8 \%$ siswa netral. Sehingga persentase terbanyak sebesar $41,7 \%$ siswa setuju bahwa guru memberikan pertanyaan bervariasi untuk diskusi masalah. Hal ini sesuai dengan hasil penelitian yang dilakukan oleh Otriana (2020) yang mengatakan bahwa setelah semua siswa sudah sesuai dengan kelompoknya guru memberikan pertanyaan yang bervariasi pada siswa. Selanjutnya siswa diminta untuk berpikir bersama dalam menyatukan pendapatnya sehingga diperoleh hasil diskusi yang tepat.

\section{Langkah 5 Memanggil Nomor Anggota atau Pemberian Jawaban}

Hasil wawancara peneliti dengan subjek penelitian dan triangulasi sumber menyatakan bahwa pada langkah ini guru memanggil salah satu nomor dari anggota kelompok untuk mempresentasikan hasil diskusi kelompoknya, pemanggilan nomor ini dilakukan secara acak sehingga siswa harus lebih mempersiapkan diri untuk menyiapkan hasil diskusinya. Hal ini dapat dilihat dari perolehan angket bahwa guru memanggil satu nomor dari tiap kelompok dengan nomor yang sama, kemudian nomor dari semua anggota kelompok yang bersangkutan mengangkat tangan untuk menyiapkan jawaban yang diperoleh persentase sebesar 19,4\% siswa sangat setuju; $41,7 \%$ siswa setuju; dan 36,1\% siswa netral. Sehingga persentase terbanyak sebesar $41,7 \%$ siswa setuju bahwa guru memanggil satu nomor dari tiap kelompok agar mengangkat tangan dan menyiapkan jawaban. Hal ini sesuai dengan hasil penelitian yang dilakukan oleh Darmada (2017) dan Paembonan, Hamid, \& Rocmaniah (2014) yang menyampaikan bahwa pada tahap ini guru memanggil satu nomor dari setiap kelompok dengan nomor yang sama kemudian siswa yang nomornya sama dan dipanggil oleh guru mengangkat tangan dan menyiapkan hasil diskusinya. Selanjutnya setelah guru memanggil salah satu nomor dari anggota kelompok siswa yang bersangkutan langsung maju kemudian memaparkan hasil diskusinya dan anggota kelompok lain memberi semangat. Hal ini dapat dilihat dari perolehan angket bahwa guru meminta siswa dari tiap kelompok yang nomornya dipanggil agar memaparkan hasil jawaban di depan kelas yang diperoleh persentase sebesar $27,8 \%$ siswa sangat setuju; 47,2\% siswa setuju; dan 22,2\% siswa netral. Sehingga persentase terbanyak sebesar $47,2 \%$ siswa setuju bahwa guru meminta siswa dari setiap kelompok agar memaparkan hasil jawabannya. Hal ini sesuai dengan hasil penelitian yang dilakukan oleh Agustin (2018) yang mengungkapkan bahwa ketika siswa selesai berdiskusi salah satu nomor akan dipanggil oleh guru untuk mempresentasikan hasil diskusinya di depan kelas dan siswa mempersiapkan jawaban atas diskusi kelompoknya kemudian memaparkannya di depan kelas.

Selesai memaparkan hasil diskusi, kelompok lain memberikan tanggapan, kemudian guru memberikan penilaian terhadap keaktifan siswa selama menggunakan model pembelajaran NHT. Hal ini dapat dilihat dari perolehan angket bahwa guru memberikan penilaian terhadap pemaparan hasil jawaban siswa di depan kelas yang diperoleh persentase sebesar $25 \%$ siswa sangat setuju; 44,4\% siswa setuju; dan 30,6\% siswa netral. Sehingga persentase terbanyak sebesar $44,4 \%$ siswa setuju bahwa guru memberikan penilaian pemaparan terhadap hasil jawaban siswa di depan kelas. Hal ini sesuai dengan hasil penelitian yang dilakukan oleh Kumoro (2011) yang mengemukakan bahwa guru memberikan penilaian terhadap pemaparan hasil dari diskusi siswa, dimana terdapat 2 jenis penilaian yang digunakan oleh guru yaitu penilaian proses dan penilaian hasil. Dalam hal ini penilaian proses dilakukan ketika masing-masing kelompok berdiskusi, sedangkan penilaian hasil dilakukan berdasarkan hasil dari pemaparan diskusi kelompok. 


\section{Langkah 6 Memberikan Kesimpulan}

Hasil wawancara peneliti dengan subjek penelitian dan triangulasi sumber menyatakan bahwa pada langkah ini yaitu memberi kesimpulan. Setelah adanya tanggapan dari kelompok lain, guru memberikan evaluasi terkait apa yang dipaparkan oleh siswa tersebut berupa saran dan masukan. Hal ini dapat dilihat dari perolehan angket bahwa guru mengevaluasi hasil jawaban siswa yang diperoleh persentase sebesar 36,1\% siswa sangat setuju; 44,4\% siswa setuju; dan $16,7 \%$ siswa netral. Sehingga persentase terbanyak sebesar $44,4 \%$ siswa setuju bahwa guru melakukan evaluasi terhadap hasil jawaban siswa. Hal ini sesuai dengan hasil penelitian yang dilakukan oleh Saputra (2014) dan Wahyuningsih \& Muwarni (2015) yang menyatakan bahwa pada tahapan ini guru melakukan refleksi dan evaluasi dengan memberikan tanggapan pada semua hasil diskusi kelompok. Sebelum mengakhiri pembelajaran guru memberikan waktu kepada siswa untuk bertanya terkait dengan materi yang telah disajikan. Siswa yang merasa kurang paham diminta untuk mengangkat tangan kemudian bertanya pada guru. Hal ini dapat dilihat dari perolehan angket bahwa guru bersama siswa menyimpulkan jawaban akhir dari semua pertanyaan yang berhubungan dengan materi yang disajikan yang diperoleh persentase sebesar 41,7\% siswa sangat setuju; 38,9\% siswa setuju; dan 13,9\% siswa netral. Sehingga persentase terbanyak sebesar $41,7 \%$ siswa sangat setuju bahwa guru dan siswa menyimpulkan bersama jawaban akhir dari semua pertanyaan. Hal ini sesuai dengan hasil penelitian Fitriani, Kurniati, \& Fadhilah (2017) yang menyatakan bahwa pada tahap yang terakhir ini guru meminta siswa untuk menyimpulkan hasil diskusi kelompok, setelah itu guru juga memberikan kesimpulan di akhir pembelajaran.

Sebelum mengakhiri pembelajaran, guru mengajak siswa untuk berdoa bersama dan mengucapkan salam. Hal ini dapat dilihat dari perolehan angket bahwa guru mengucapkan salam dan mengakhiri kegiatan pembelajaran yang diperoleh persentase sebesar 83,3\% siswa sangat setuju; 8,3\% siswa setuju; dan 5,6\% siswa netral. Sehingga persentase terbanyak sebesar $83,3 \%$ siswa sangat setuju bahwa guru mengucapkan salam lalu mengakhiri kegiatan pembelajaran. Hal ini sesuai dengan hasil penelitian yang dilakukan oleh Selmi, Hasbi, \& Lefrida (2017) yang menjelaskan bahwa kegiatan menutup pembelajaran adalah memberikan penghargaan berupa tepuk tangan dan pujian setelah itu diakhiri dengan mengucapkan salam. Penggunaan model pembelajaran NHT dapat menjadikan siswa untuk lebih memahami konsep materi yang dipelajari. Hal tersebut diperkuat oleh jawaban siswa yang mengungkapkan bahwa dengan menggunakan model pembelajaran NHT siswa lebih mudah mengingat materi pelajaran, dapat mendorong siswa untuk lebih aktif dalam proses pembelajaran, dapat melatih kepercayaan diri siswa ketika mengungkapkan pendapatnya, serta dapat menumbuhkan kesadaran dan tanggung jawab siswa terkait tugas yang diberikan oleh guru. Disamping itu peserta didik lebih konsentrasi dalam memahami instruksi yang diberikan oleh pendidik dan lebih konsentrasi terhadap bahan atau materi ajar yang diberikan oleh pendidik (Liubana \& Puspasari, 2021).

\section{KESIMPULAN DAN REKOMENDASI}

Berdasarkan hasil dan pembahasan dapat disimpulkan bahwa model pembelajaran Numbered Head Together (NHT) merupakan model pembelajaran yang menuntut siswa untuk dapat saling berdiskusi dengan kelompoknya sehingga proses pembelajaran menjadi lebih komunikatif. Adanya model pembelajaran NHT dapat melatih rasa tanggung jawab siswa terhadap tugas yang diberikan oleh guru serta dapat melatih keberanian siswa untuk mengungkapkan pendapatnya baik di dalam kelompok maupun di depan kelas. Dalam penerapan model pembelajaran NHT melalui 6 langkah yaitu: Langkah 1 Persiapan: guru menyiapkan skenario pembelajaran beserta dengan materi dan penugasan serta Lembar Kerja 
Siswa (LKS) yang akan diberikan pada siswa yang disesuaikan dengan langkah-langkah kegiatan pembelajaran dengan menggunakan model pembelajaran NHT; Langkah 2 Pembentukan Kelompok: guru membentuk kelompok menjadi 6 kelompok dan masingmasing kelompok beranggotakan 6 orang siswa berdasarkan urutan yang ada di presensi. Selanjutnya guru memberi nomor kepada setiap siswa dalam kelompok dan nama kelompok dengan nama yang berbeda untuk mempresentasikan hasil diskusi kelompoknya; Langkah 3 Pengamatan: guru memastikan siswa mempunyai buku paket untuk mempermudah siswa dalam menyelesaikan tugas pada LKS dan melakukan pengamatan kepada setiap kelompok dalam menyelesaikan penugasan yang ada di LKS; Langkah 4 Diskusi Masalah: guru meminta siswa untuk dapat bekerja sama dengan kelompoknya dan saling mengungkapkan pendapatnya dengan tujuan agar siswa dapat berinteraksi bersama dengan anggota kelompoknya dan saling membantu satu sama lain dalam memecahkan masalah, siswa dapat bertukar pikiran sehingga menemukan solusi bersama. Selanjutnya guru memberikan pertanyaan bervariasi dari yang bersifat spesifik sampai yang bersifat umum untuk diskusi masalah; Langkah 5 Memanggil Nomor Anggota atau Pemberian Jawaban: guru memanggil salah satu nomor dari anggota kelompok untuk mempresentasikan hasil diskusi kelompoknya yang dilakukan secara acak sehingga siswa harus lebih mempersiapkan diri untuk menyiapkan hasil diskusinya. Kemudian guru memberikan penilaian terhadap keaktifan siswa selama menggunakan model pembelajaran NHT; Langkah 6 Memberikan Kesimpulan: guru memberikan kesimpulan berupa evaluasi terkait pemaparan yang dilakukan oleh siswa dalam bentuk saran dan masukan. Guru bersama dengan siswa memberikan kesimpulan di akhir pembelajaran.

\section{DAFTAR PUSTAKA}

Agustin, M. N. (2018). Upaya Meningkatkan Aktivitas Belajar Biologi Siswa melalui Model Pembelajaran Kooperatif Tipe Numbered Head Together (NHT) yang Diawali dengan Pemberian Tugas Rumah di Kelas X.3 SMAN 1 Pujung. Jurnal Inovasi Pendidikan, 5(1), 1-9. http://jurnal.umsb.ac.id/index.php/inovasipendidikan/article/view/800.

Darmada, K. (2017). Implementasi Model Pembelajaran Kooperatif Tipe Numbered Head Together (NHT) untuk Meningkatkan Hasil Belajar. Jurnal Pendidikan FKIP UNIPAS, 04(3), 1-11. https://ejournal.unipas.ac.id/index.php/DW/article/view/31.

Fathurrohman, M. (2017). Model-model Pembelajaran Inovatif. Yogyakarta: Ar-Ruzz Media. Fatimatuzzahroh, S. \& Puspasari, D. (2021). the Influence of Using Typing Master Application Media on 10 Finger Typing Skills in Office Technology Subjects at SMK Muhammadiyah 2 Sumberrejo Bojonegoro. Jurnal Mantik, 5(1), 1-6. https://iocscience.org/ejournal/index.php/mantik/article/view/1249.

Fauziah. (2020). Peningkatan Hasil Belajar Fisika pada Materi Pokok Alat-alat Optik melalui Model Pembelajaran Numbered Head Together (NHT) pada Siswa Kelas X IPA-1 SMA Negeri 1 Meulaboh. Jurnal Pendidikan, Sains, dan Humaniora, 8(2), 248-257. http://ojs.serambimekkah.ac.id/serambi-akademika/article/view/2258.

Fauzi, A., et al. (2020). The Use of Numbered Heads Together to Improve the 10th Grade Student's Reading Comprehension Achievement at MAN 2 Lamongan. Indonesian $\begin{array}{llll}\text { Journal of } & \text { English } & \text { 118-123. }\end{array}$ http://jurnalftk.uinsby.ac.id/index.php/IJET/article/view/623.

Fitriani, Kurniati, T., \& Fadhilah, R. (2017). Pengaruh Model Kooperatif Tipe Numbered Head Together (NHT) Bersetting Problem Possing terhadap Hasil Belajar Siswa Pokok Bahasan Stoikionemetri Kelas X IPA SMA Negeri 8 Pontianak. Jurnal Ilmiah Ar-Razi, 5(1), 30-44. http://openjurnal.unmuhpnk.ac.id/index.php/ar-r/article/view/651. 
Hariana, H. C. (2018). Improvement of Student Geography Learning Achievement through Application of Cooperative Learning Model Type "Numbered Head Together" in X Grade SMAN 2 Watansoppeng. UNM Geographic Journal, 1(1), 48-54. https://ojs.unm.ac.id/index.php/UGJ/article/view/5561.

Hutahean, J. (2014). Pengaruh Model Pembelajaran Kooperatuf Tipe Numbered Head Together (NHT) dengan Menggunakan Media Mind Mapping terhadap Hasil Belajar Siswa Kelas XI Semester 2 pada Materi Pokok Fluida Statis di SMA Negeri 10 Medan TP.2013/2014. Journal Inovasi Pembelajarn Fisika, 2(4), 61-67. https://jurnal.unimed.ac.id/2012/index.php/inpafi/article/view/2122.

Khairina, A., Zamakhsyari, \& Hidayat, R. (2017). Penerapan Model Pembelajaran Cooperative Tipe Numbered Heads Together dalam Meningkatkan Motivasi Belajar pada Mata Pelajaran PAI di Kelas XI Sosial SMA Dharmawangsa. Jurnal Ilmu Keislaman, 2(2),

51-76. http://jurnal.dharmawangsa.ac.id/index.php/almufida/article/view/63.

Kumoro, A. (2011). Peningkatan Hasil Belajar Siswa melalui Model Numbered Head Together (NHT) dalam Mata Pelajaran Sistem Koloid Siswa Kelas XI SMA. Jurnal Inovasi Pendidikan, 2(2), 81-90. https://ppjp.ulm.ac.id/journal/index.php/quantum/article/view/1362.

Lestari, D., dkk. (2020). Efektivitas Metode Pembelajaran Numbered Head Together (NHT) terhadap Kemampuan Pemecahan Masalah Matematis Siswa di Kelas X SMA Swasta Bina Artha. Mathematic Education Journal, 3(1), 19-28. http://journal.ipts.ac.id/index.php/MathEdu/article/view/1161.

Liubana, A. \& Puspasari, D. (2021). Analisis Pengaruh Penggunaan E-Learning dengan Google Classroom dan Disiplin Belajar terhadap Motivasi Belajar Mahasiswa Brothers and Sisters House Kota Surabaya pada Masa Pandemi Covid-19. Jurnal Kependidikan: Jurnal Hasil Penelitian dan Kajian Kepustakaan di Bidang Pendidikan, Pengajaran dan Pembelajaran, 7(2), 417-427. $\underline{\text { https://e- }}$ journal.undikma.ac.id/index.php/jurnalkependidikan/article/view/3599.

Mislani. (2018). Kurikulum 2013 dan Guru Inovatif. Kompasiana.com. (https://www.kompasiana.com/maslani/5bd6f996677ffb1f0a7a8bc9/kurikulum-2013dan-guru-inovatif?page=all, diakses pada tanggal 02 Mei 2020).

Nurhadisah, Halim, A., \& Khaldun. I. (2014). Pembelajaran Kooperatif Tipe Numbered Head Together dengan Pendekatan Inkuiri untuk Meningkatkan Penguasaan Konsep Kalor Siswa SMA. Jurnal Pendidikan Sains Indonesia, 02(01), 54-64. http://erepository.unsyiah.ac.id/JPSI/article/view/7633.

Otriana, R. (2020). Peningkatan Kemampuan Penguasaan Materi Metabolisme melalui Penerapan Model Pembelajaran NHT (Numbered-Head Together). Jurnal Kinerja Pendidikan, 2(4), 666-683. http://ojs.serambimekkah.ac.id/JKK/article/view/2452.

Paembonan, R. D., Hamid, A., \& Rocmaniah, S. (2014). Penerapan Model Pembelajaran Kooperatif Tipe Numbered Heads Together untuk Meningkatkan Hasil Belajar Siswa pada Materi Penarikan Kesimpulan Logika Matematika di Kelas X SMA GDIP Palu. Jurnal Elekrtonik Pendidikan Matematika Tadulako, 2(1), 99-107. http://jurnal.fkip.untad.ac.id/index.php/jpmt/article/view/229.

Rahayu, M. (2018). Peningkatan Hasil Belajar dan Keaktifan Siswa Pembelajaran Akuntansi Materi Jurnal Umum melalui Model Pembelajaran Kooperatif Tipe NHT pada Siswa XII IPS 1 SMAN 4 Penajam Paser Utara. Jurnal Ilmiah Pendidikan Humaniora, 4(5), 659-672. http://www.publikasiilmiah.com/wp-content/uploads/2018/10/12.-MESY659-672.pdf.

Saputra, A. D. (2014). Penerapan Model Pembelajaran Kooperatif Tipe Numbered Head 
Together (NHT) untuk Meningkatkan Hasil Belajar Ekonomi Siswa Kelas XI IS SMAN 1 Singaraja Kabupaten Buleleng pada Semester Ganjil Tahun 2013/2014. Jurnal Pendidikan Ekonomi, 40-50. https://ejournal.undiksha.ac.id/index.php/EKU/article/download/12774/8030.

Selmi, Hasbi, M., \& Lefrida, R. (2017). Penerapan Model Pembelajaran Kooperatif Tipe Numbered Heads Together untuk Meningkatkan Hasil Belajar Siswa dalam Menyelesaikan Pertidaksamaan Kuadrat di Kelas X B SMA GKST Imanuel Palu. $\begin{array}{llll}\text { Jurnal Pendidikan } & \text { Matematika, 217-229. }\end{array}$ https://doi.org/10.23887/ijee.v1i2.11603.

Sembiring, M. B. (2014). Penerapan Pembelajaran Persamaan Diferensial dengan Menggunakan Model Kooperatif Numbered Heads Together dan Teams Games Tournament. Journal of Mathematic Education and Science, 2(1), 52-57. https://jurnal.uisu.ac.id/index.php/mesuisu/article/view/116.

Simanungkalit, M. (2020). Penerapan Pembelajaran Aktif Kooperatif melalui Metode Numbered Head Together (NHT) sebagai Upaya Meningkatkan Aktivitas dan Hasil Belajar IPA-Biologi. Jurnal TIK Pendidikan, 7(1), 89-102. https://jurnal.unimed.ac.id/2012/index.php/teknologi/article/view/22635.

Siregar, R. (2016). Peningkatan Prestasi Belajar Sejarah melalui Metode Pembelajaran Kooperatif Numbered Head Together (NHT) Siswa Kelas XI IPS 2 SMA Negeri 1 Tebing Tinggi. Jurnal Handayani, 5(2), 172-186. https://jurnal.unimed.ac.id/2012/index.php/handayani/article/view/6533.

Sudarmanto, E., Fitriana, A., Malau, M., Nainggolan, C. D., Zunaidi, A., Manurung, S., ... \& Hidayat, G. (2021). PENGANGGARAN PERUSAHAAN.

Sugiyono. (2019). Metode Penelitian Kuantitatif, Kualitatif, dan R\&D. Bandung: Alfabeta.

Sujatna, N. (2014). Penerapan Model Pembelajaran Kooperatif Tipe Numbered Head Together untuk Meningkatkan Keterampilan Berkomunikasi dan Prestasi Belajar Siswa. Jurnal Teknologi Pendidikan dan Pembelajaran, 1(1), 89-98. https://jurnal.untirta.ac.id/index.php/JTPPm/article/view/7900.

Sulfiani, R. (2016). Penerapan Model Pembelajaran Kooperatif Tipe Numbered Head Together (NHT) untuk Meningkatkan Hasil Belajar Kimia Siswa Kelas XI IPA1 SMA Negeri 3 Watampone Studi pada Materi Pokok Struktur Atom, Sistem Periodik Unsur dan Bentuk Molekul). Jurnal Cheremical, 17(1), 1-13. http://jurnal.dharmawangsa.ac.id/index.php/almufida/article/view/63.

Syairozi, M. I. (2017). Percepatan Pengurangan Kemiskinan Sektor Pertanian di Kabupaten Malang. In Seminar Nasional \& Call For Paper, FEB Unikama (pp. 145-155).

Turangan, N. M. (2017). Aplikasi Model Pembelajaran Kooperatif Tipe Numbered-HeadTogether sebagai Upaya Peningkatan Prestasi Belajar Matematika. Journal Ilmiah Pro Guru, 3(4), 444-450. http://journal2.um.ac.id/index.php/jipg/article/view/19924.

Wahyuningsih, D. \& Muwarni, S. (2015). Peningkatan Aktivitas dan Hasil Belajar Siswa pada Pembelajaran Biologi melalui Model Numbered Head Together pada Siswa Kelas XI SMA Negeri 2 Yogyakarta. Jurnal Pendidikan Matematika dan Sains, 3(1), 65-71. https://journal.uny.ac.id/index.php/jpms/article/view/7237.

Wibowo, E. (2018). Penerapan Model Pembelajaran NHT (Numbered Heads Together) dalam Meningkatkan Pemahaman Konsep Matematika Trigonometri untuk Kelas X MIPA 3 di SMK Negeri 1 Luwuk. Jurnal Linear, 02(03), 70-82. https://ojsuntikaluwuk.ac.id/index.php/linear/article/view/105.

Widyastuti, W. (2016). Peningkatan Aktivitas dan Hasil Belajar Biologi melalui Penerapan Metode Numbered Head Together pada Siswa Kelas X SMA Bantul. Jurnal Ilmiah Guru, 2(1), 1-7 https://journal.uny.ac.id/index.php/cope/article/view/10787. 
Zaura, B., Elianti, \& Syah, R. (2018). Ketuntasan Hasil Belajar Siswa melalui Model Pembelajaran Kooperatif Tipe Numbered Head Together (NHT) pada Materi Program Linier di Kelas XI IA5 SMA Negeri 4 Banda Aceh. Jurnal Serambi PTK, 5(1), 1-6. http://ojs.serambimekkah.ac.id/serambi-ptk/article/view/602. 